\title{
The ways of formation health saving educational environment for schoolchildren in Ukraine
}

\author{
Tetiana Yermakova \\ Kharkiv State Academy of Design and Arts, Ukraine
}

Keywords: healthy environment; education; formation; national system; Ukraine;

\begin{abstract}
Aim: to reveal areas of problems of health saving educational environment in the national school system. Materials: it was analyzed 38 literature resources on the item of the article. Results. The main concept of the article is to single out and analyze the ways of formation and development the health saving educational environment in modern school educational system of Ukraine. The first way is national programs, where the author illuminates the main documents concerning school education and reveals the key areas of the formation of healthy environment. The second way is international programs in which Ukraine take part. Such participation aimed at improving the health of schoolchildren, equip them with the skills of healthy lifestyle, use of folk traditions, integration of healthy lifestyles in the educational process etc. The third way is school subjects with the elements of formation health saving skill and knowledge among schoolchildren and teachers at genera.
\end{abstract}

\section{Introduction}

The current level of civilization and culture brings among the number of key priorities for the man - to be healthy, but not sick. For the educational system, this problem translates into the need to use the technologies that has just teacher and psychologist.

Awareness of the problem of human health and the nation as a whole, as an important component of socio-economic, political and cultural development of the country led to the relevance of theoretical and practical development, the need for deployment of the relevant research, the development of new methodological approaches to the formation, 
preservation, enhancement and healthcare of every person. Where, in particular, the important role belongs to the educational system.

As obvious influence of education on the health of Ukrainian schoolchildren grow, as an interest of scientists to the substantiation and creation of appropriate health saving conditions in the schools of the country increase (N. Bibik, T. Boychenko, O. Dubogay, T. Chernenko, O. Savchenko, S. Shmalyey, V. Shpak) [3; 7; 13; 30; 32; 34; 34]. There are also a number of comparative investigations concerning the peculiarities of organization of education process at schools in the context of schoolchildren health saving (T. Iermakova, O. Ionova, O. Lukashenko, S. Luparenko) [20; 36; 37], preparation of future teachers to promote healthy lifestyle among schoolchildren (V. Bobrytska, Yu. Boychuk, M. Goncharenko) [5; 9; 11].

In addition, the gradual realization of state-level importance of prevention, preservation, maintenance and restoration of the nation's health involves finding ways of increasing awareness in the younger generation values health and a healthy lifestyle.

In this article, the author represents the main ways of formation health saving educational environment for schoolchildren in Ukraine such as: the component of health saving of schoolchildren in national programs; the influence and participation of Ukraine in international programs; school subjects that have health saving elements in the structure.

Aim - to reveal areas of problems of health saving educational environment in the national school system. Material: it was analyzed 38 literature resources on the item of an issue.

\section{Results}

I. National programs. Modern domestic regulatory framework of education (National Strategy of the Development of Education in Ukraine until the year 2021 [25]; National Doctrine of education [24]; State standard of basic and secondary education [12]; The concept of general secondary education (12 year school) [17]; The concept of formation of positive motivation for a healthy lifestyle for children and young people (2004) [23]; Intersectoral complex program "Health of the nation" for years 2002-2011 [21] etc.) includes not only care about the health of the younger generation, but also education in young and the principles of healthy living, care about their health. Introduced documents in Ukraine preconditions for updating content and technology training and education, changed view of education as a process of overcoming the negative trends in personal development, schoolchild involvement in the system of values. In addition, as shown by the analysis of these documents, their contents directed mainly to a healthy 
lifestyle of schoolchildren, not to justify the theoretical and practical areas of health culture of the growing generation.

Theoretical analysis of the contents of these documents allowed determining that education in Ukraine designed to provide training both various groups throughout life and specialists in various fields at all stages of their professional activities. In addition, the educational process itself, including health issues, should be based on the subjects that will enable to not only deepen schoolchildren knowledge and implement interdisciplinary communication, but also to demonstrate their connection with educational material everyday life, teach care about their health. Moreover, the formation of healthy lifestyle because of education, announced the general criteria of assessment of schoolchildren achievements, which states that the purpose of education should be formed of competence as a general ability based on knowledge, experience and personal values.

The key areas of public education policy in Ukraine are as follows: the formation of healthy environment, greening valeological education and culture of the participants of the educational process, the center of which is a healthy lifestyle as a part of education, preservation and strengthening of health of children and young people, providing their balanced nutrition, health center; increase in motor mode of schoolchildren by the lessons of physical culture, mass sports and sports, recreation activities after school, improvement of sports and recreation and sports-media work in educational institutions and other agencies (extension of a number of sports clubs, sections and clubs required omitted personnel, financial, material and technical provision of their activities); update methodology of physical education of children and youth with direct valeological support of the whole process of training and education of children with different physical and educational opportunities.

II. International programs. During the time of independence, Ukraine has gone through the process of building a democratic state and a new institutional environment that provides the improvement of social welfare, legal protection of children [4]. The problems of this transition resolved with varying degrees of success. The plain fact is the positive impact on the process of cooperation at the international level.

Note that Ukraine takes part in international programs ("Health and behavioral orientation of schoolchildren", "Healthy children - healthy nation", "European school survey project on alcohol and other drugs", "Development of national policy implementation the rights of children living with HIV", "Overcoming HIV / AIDS epidemic in Ukraine") and some European projects ("Youth for health", "Youth - for healthy life", "Healthy lifestyle - it is fashionable!") aimed at improving the health of schoolchildren, equip them with the skills of healthy lifestyle, use of folk traditions, 
tempering body and soul, refusal of bad habits; integration of healthy lifestyles in the educational process. Most of the above named programs and projects based on structural and logical model of a health culture and healthy lifestyles of schoolchildren, which takes into account such criteria as physical health, mental health (psychological comfort), mental health, social health (social welfare) and their performance.

It should also emphasized that the international community actively promotes and supports the activities of non-governmental organizations in Ukraine. In particular, it should be noted Ukrainian charity organization "Ukrainian Fund" "Child Well-Being", which has existed since 2003 with the support of the Directorate on a matter of development and cooperation of Switzerland; Ukrainian Foundation "Step by Step" implements the project "'CCreation of resource centers for parents of children with special educational needs" with the support of TACIS program "Development of Organizational Partnership" of the European Commission, which aims to defend the rights and interests of children with special educational needs, needs assessment and provide providing educational, social and other services and the expansion parents active citizenship and promote the creation of parent organizations; sequentially Council of Europe program "To build Europe for and with children", which was launched in 2006 under the mandate of the Third Summit of Heads of State and Government of the Council of Europe (Warsaw, Poland, 2005), which aims to help countries in the design and development of the national strategy to protect the rights of children [28].

A major incentive to the promotion of healthy schoolchildren became an accession of Ukraine to the international project "The European School Survey Project on Alcohol and Other Drugs" (1995) with the support of the Ministry of family, youth and sports, Ministry of education of Ukraine, the UN Children's fund (UNICEF), World health organization, the International HIV / AIDS [14]. According to this project every four years take place the social survey of schoolchildren about their level of skills and knowledge in healthy lifestyle, HIV and AIDS preventive measures, general knowledge in strengthening and saving their own health and health of others. Note that the survey takes place by selfcompletion questionnaires in classrooms under the conditions of anonymity, ensuring respect for human dignity and ethical standards in accordance with approved Sociological Association of Ukraine ethical research among children and adolescents, the principles of the Helsinki Declaration of Human Rights, Council of Europe Convention human rights, Convention on the rights of the child and the relevant laws of Ukraine.

III. School subjects. One of the important mechanisms of socialization of modern man is education, which is a hierarchy of goals, objectives and priorities of training and education of the growing generation. In modern psychological and pedagogical literature, 
education is reviewed in the following directions: as the educational system, as the educational process, as the educational activities, as an individual or aggregate result of the process and learning environment [38].

Today the school environment plays an important role in the development of the individual, satisfying his / her spiritual needs, identifying personal life and the further socialization. The atmosphere of favorable environment of the educational establishment must be based on trust and love, empathy, positive tone of the relationships that define success as a promising line of general educational institutions and all subjects of the educational process.

Note that in the 80 's XX century Ukrainian educational thought, appeared a new term "valeology" (introduced by the Russian teacher I. Brekhman), which noted the need to develop methodological foundations that preserve and promote health and healthy people [8]. Since then, the term has become common, and valeology as science and academic discipline ("Basics of valeology") is becoming more widely recognized. Thus, in the present study are common terms "valeological education" and "valeological pedagogics". L. Tatarnikova rightly says that valeological education is a process of selfregulation, self-reflection of the individual, based on an individual philosophy of health, which combines intellectual and social equal rights [31]. Valeological education aimed at training the individual needs of a healthy lifestyle. Valeological education is a branch of knowledge about the formation of health of schoolchildren by pedagogical methods, and its main criterion is not harming the health of schoolchildren.

Significant boost to the development of valeology promoted the Conference of Ministers of Health of the European countries, held in Madrid (Spain) in 1981, where it was decided - to consider education as a priority direction of health. That it was about improving health through education. This decision was sent to all schools participating countries meeting.

A significant contribution to the formation and development of Ukrainian valeology was made by such scholars as I. Anosov, V. Afanas'ev, T. Boychenko, Yu. Lisytsyn and others, who have proved the necessity and importance of valeological training and education, its impact on human life and the development of diseases smoking, alcohol, drugs, etc., in need of each person to think about their health $[1 ; 2 ; 6 ; 18]$.

Besides "Basics of valeology" as a subject in schools of our country was introduced integrated course "Basics of health", whose main task is: the formation of an idea that health is considered as a whole and its components are physical, social, mental and spiritual; development of schoolchildren ideas and concepts of the interactions of the human body with the natural and social environment; building knowledge and skills 
of safety of life at home, at school, on the street and in public places; forming ability to foresee the consequences of their actions, to carry out self-assessment of their own actions and evaluate the actions of others; forming the ability to provide self and mutual self-appraisal and health; active development of schoolchildren motivation to maintain and promote health, self-improvement of physical, social, mental and spiritual components of health; developing the ability to govern themselves and resolve conflicts in life; contact with people in society, resist the negative influence of the environment; developing the ability to predict the potential danger in microsociety, the environment, make the right decisions independently, creatively and think critically; education needs in health as an important life values $[27 ; 28]$.

On the content of the training course "Basics of health" fully intended to ensure the implementation of meaningful and motivational block a health culture of schoolchildren because of their ability to equip schoolchildren with the necessary knowledge formation, preservation and promotion of health, to promote understanding of the essence of the culture of health as the highest social value. It should be noted that the introduction of these subjects is an important step in becoming schoolchildren systematic knowledge about their health and ways to strengthen and save. Thus, in addition to schooling embedded objects whose meaning has health saving components, significant role get health saving technologies (I. Babin, T. Chernenko, M. Goncharenko, O. Ionova, V. Yefimova etc.), considered as a qualitative characteristic of any educational technology, its "certificate of security for health" and as a set of principles, techniques, methods of teaching that are complementing traditional technology training and education $[9 ; 10$; $15 ; 16 ; 26]$.

Thus, in educational institutions of Ukraine main role in formation of schoolchildren health culture formation plays educational, extracurricular and after-school activities. According to the explanatory note to the program "Education XXI" (Ukraine) to study all school subjects accounted for $80 \%$ of teaching time, of which $35 \%$ allocated to social and humanitarian subjects, $25 \%$ - natural sciences and mathematics, $15 \%$ - health and labor, $5 \%$ - aesthetic. In educational activities to solve the abovementioned problem highlighted items concerning health problems, such as: "Physical Culture", "Man and Society", "Biology", "'’Environment", "Homeland Security”, “Basics of Health”, “Labor studies", "Nature" [22]. Considering that the integrated system promoting healthy lifestyles, strengthening and formation of health education in matters of health culture of schoolchildren in secondary schools so far observed mainly at the level of theory, not practice. Today face an urgent production single concept, the new cross-curriculum learning the basics of a healthy lifestyle of schoolchildren. 
The main types of extracurricular activities of schoolchildren that have a positive impact on their health include competitions of newspapers, pictures, production of booklets, creating electronic presentations and movies in order to promote healthy lifestyles, monthly days of crime prevention and more. In extracurricular activities predominate sports competitions and races, trips, after-school activities in education and educational institutions to attract schoolchildren to community organizations, students stay in the camps.

\section{Conclusions.}

Thus, our analysis research confirmed that in the present conditions of our country carried out purposeful process of targeting children and young people a healthy lifestyle, forming their health culture. However, failure to resolve this issue at this stage is related primarily to the lack of study and implementation of promising teaching experience, developing innovative educational technology training and retraining of the teaching staff to implement the task of creating a culture of health.

Conflict of interest. The author proved that there is no conflict of interest.

\section{References}

1. Аносов І.П. Антропологізм як чинник гуманізації освіти (теоретикоконцептуальні основи): автореф. дис. ... доктора пед. наук: 13.00.01 / I.П. Аносов. - Київ, 2004. - 44 с.

2. Афанасьев В.Г. О системном подходе в социальном познании / В.Г. Афанасьев // Вопросы философии. - 1973. - № 6. - С. 99-101.

3. Бібік Н.М. Компетентнісний підхід у сучасній освіті: світовий досвід та українські перспективи: бібліотека 3 освітньої політики / Н.М. Бібік, Л.С. Ващенко, О.І. Локшина та ін. - К.: К.І.С., 2004. - 168 с.

4. Бідність та нерівні можливості дітей в Україні / Л.М. Черенько, С.В. Полякова, А.Г. Реут та ін.; [за ред. Е. М. Лібанової]. - К.: Ін-т демографії та соціальних досліджень НАН України, Дитячий фонд ООН (ЮНІСЕФ), Український центр соціальних реформ, 2009. - 288 с.

5. Бобрицька В.І. Формування здорового способу життя у майбутнього вчителя: [монографія] / В.І. Бобрицька. - Полтава: Снайтек, 2006. - 431 с.

6. Бойченко Т. Валеологія в школі і дома / Т. Бойченко. - Київ: Логос, 1999.

7. Бойченко Т.Є. Формування здоров'язбережливої компетентності учнівської молоді / Т.Є. Бойченко // Професійна освіта. - 2009. - № 1. - С. 41-44.

8. Брехман И.И. Введение в валеологию - науку о здоровье / И.И. Брехман. - Л.: Наука, 1987. - 123 с.

9. Гончаренко М.С. Валеология в схемах / М.С. Гончаренко. - Харьков, 2003. - 187 c.

10. Гончаренко М.С. Валеологічне розвантаження школярів протягом навчального процесу: [навч.-метод. посібник для вчителів] / М.С. Гончаренко, Г.В. Ткаченко, Н.В. Самойлова. - Харків, 2005. - 72 с.

11. Гончаренко М.С. Екологічна валеологія: словник-довідник / М.С. Гончаренко, Ю.Д. Бойчук. - Харків: ХНУ ім. В.Н.Каразіна, 2007. - 224 с.

12. Державний стандарт базової і повної загальної середньої освіти [Електронний pecypc]. - Режим доступу до сайту: http://zakon4.rada.gov.ua/laws/show/13922011-\%D0\%BF 
13. Дубогай О.Д. Фізкультура як складова здоров'я та успішного навчання дитини: [метод. мат.] / О.Д. Дубогай. - К.: Шк. світ, 2006. - 128 с.

14. Європейське опитування учнівської молоді щодо вживання алкоголю та наркотичних речовин [Електронний ресурс]. - Режим доступу до сайту: http://pres.in.ua/yevropejseke-opituvannya-uchnivsekoyi-molodi-shodo-vjivannyaa.html

15. Сфимова В.М. Формирование культуры здоровья в индивидуализирующемся социуме / В.М. Єфимова. - Х.: ПП Вишемирський В.С. - 2006. - 274 с.

16. Ионова Е.Н. Здоровьесохранение личности как психолого-педагогическая проблема / Е.Н. Ионова, Ю.С. Лукьянова // Педагогика, психология и медикобиологические проблемы физического воспитания и спорта. - 2009. - № 1. - С. 69-72.

17. Концепція загальної середньої освіти (12-річна школа) // Моделі розвитку сучасної української школи: Всеукр. науково-практична конф., 11-13 жовтня 2006 р., Черкаси - Сахнівка. - К.: СПД Богданова А.М., 2007. - 240 с.

18. Лисицин Ю.П. Теория медицины ХХ века / Ю.П. Лисицин. - М.: Медицина, 1999. - $172 \mathrm{c}$.

19. Лукашенко О.М. Навчання як «терапія»: досвід вальдорфської школи / О.М. Лукашенко //Педагогіка та психологія. - 2007. - Вип. 32. - С. 191-196.

20. Лупаренко С.Є. Розвиток пізнавальної активності молодших школярів засобами вальдорфської педагогіки: автореф. дис. на здобуття наук. ступеня канд. педаг. наук: спец. 13.00.09 «Теорія навчання» / С.С. Лупаренко. - Харків, 2008. - 20 с.

21. Міжгалузева комплексна програма «Здоров’я нації» на 2002-2011 pp. // Основи здоров'я: книга для вчителя. - К., 2005. - С. 57-62.

22. Наказ Міністерства № 834 від 27.08. 2010 «Про затвердження Типових навчальних планів загальноосвітніх навчальних закладів III ступеню» зі змінами внесеними наказом МОН України від 29.05.2014 № 657, наказом МОН України від 07.08.2015 № 855 [Електронний ресурс] / Міністерство освіти і науки України. - Режим доступу до сайту: http://mon.gov.ua/activity/education/zagalnaserednya/navchalni-plany.html

23. Наукові підходи до педагогічних досліджень: [колективна монографія / За заг. ред. д.П.н., проф., чл.-кор. НАПН України В.І. Лозової]. - Х.: Вид-во Віровець А.П. «Апостроф», 2012. - 348 с.

24. Національна доктрина розвитку освіти України у XXI ст. - К.: Шкільний світ, 2001. $-21 \mathrm{c}$.

25. Національна стратегія розвитку освіти в Україні на 2012-2021 pp. [Електронний pecypc]. - Київ, $2012 . \quad$ - 2 Режим доступу: http://www.mon.gov.ua/images/files/news/12/05/4455.pdf

26. Омельченко О.В. Характеристика моделі здоров'язберігаючої професійнопедагогічної діяльності вчителя початкових класів / О.В. Омельченко // Педагогіка, психологія та медико-біологічні проблеми фізичного виховання i спорту. - 2007. - № 2. - С. 94-97.

27. Основи здоров'я (5-9 класи). Програми для загальноосвітніх навчальних закладів. - К.: Ірпінь, 2005. - 48 с.

28. Основи здоров'я і фізична культура. Програма для загальноосвітніх навчальних закладів. 1-11 класи. - К.: Початкова школа. $-2001 .-112$ с.

29. Реформування соціальної політики в Україні: проблеми та перспективи / [авт. кол.: В.А. Скуратівський, В.П. Трощинський, П.К. Ситник та ін.]; [за заг. ред. В.А. Скуратівського, В.П. Трощинського]. - К.; Львів: НАДУ, 2012. - 368 с.

30. Савченко О. Вивчення особистості молодшого школяра як передумова успішної організації його навчальної діяльності / О. Савченко // Початкова школа. - 2012. - № 3 - C. $1-6$.

31. Татарникова Л.Г. Педагогическая валеология: Генезис. Тенденции развития / Л.Г. Татарникова. - СПб.: Петровский и Ко, 1995. - 352 с. 
32. Черненко Т. За здоров’ям в школу / Т. Черненко, О. Кійло // Завуч. - 2008. - № 19. - С. 56-60.

33. Чижевський Д.І. Філософія Г.С. Сковороди / Д.І. Чижевський; [Підгот. тексту та перед. сл.: Л.В. Ушкалов]. - Х.: Прапор, 2004. - 270 с.

34. Шмалей С.В. Диагностика здоровья: Практическое пособие по оздоровлению / С.В. Шмалей. - Херсон, 1994. - 208 с.

35. Шпак В.П. Інноваційна діяльність педагога в сучасному освітньореабілітаційному просторі / В.П. Шпак // Матеріали міжвузівської науковопрактичної конференції науковців, педагогічних працівників та студентів [«Інноваційна діяльність педагога в сучасному освітньому просторі»], (Умань, 25 листопада, 2015 р.). - Умань, 2015. - С. 65-68.

36. Iermakova T.S. (2014) Development of the idea of forming health culture of a person in the world educational thought. Pedagogics, psychology, medical-biological problems of physical training and sports, vol.4, pp. 8-12. http://dx.doi.org/10.6084/m9.figshare.950949

37. Ionova O.M. (2013) The formation of person's health: experience of Waldorf school. Pedagogics, psychology, medical-biological problems of physical training and sports, vol.10, pp. 35-40. http://dx.doi.org/10.6084/m9.figshare.775337

38. Okoń W. Słownik pedagogiczny / W. Okoń. - Warszawa: Wydawnictwo Akademickie „Żak”, 1998. - 68 s. 